\title{
研究会記録
}

公開シンポジウム

抗不整脈薬臨床試験のデー夕解析をめぐって

主 催 厚生省

抗不整脈薬の臨床評価方法の確立に関する研究班

世話人帝京大学医学部清水直容

東京医科歯科大学 佐久間昭

目次

1. 期外収縮に関する薬効評価の現状

帝京大学……………清水 直容……6 676

2. DCG期外収縮記録におけるサイズとパタン

東京医科歯科大学………佐久間 昭……6 677

3. 視察的概括評価の構造

東京医科歯科大学………津谷喜一郎……6 679

4. 有意性検定の注意点 
1. 期外収縮に関する薬効評価 の現状

清水直容
$(*$ 帝京大学第 1 内科 $)$

これまでの臨床評価に関する本およびFDA の臨床 治験指針には，不整脈の患者選択基準，効果判定など について具体的な記述がないので本邦で1971〜 1982年 に発表された抗不整脈薬臨床治験報告36報をレビュー し，その概括をのべる。

\section{I . 治験症例の構成（表 1，2）}

全体像としては, 期外収縮について 1 週間の観察期 間をおき，この間の心電図で不整脈が毎分 5 個以上あ るものを対象として選択し，投薬を 1 週間行い, それ による不整脈の減少を一定の基準によって判定すると いうものである。このようにして選択された患者は男 女ほぼ同数で 60 歳以上と 40 歳以下に分布し, 心室性の ものが上室性のものの 2 倍近く治験対象となってい る。選択された患者の不整脈数は毎分10２9個のもの が70\%をしめる。症例の70\%は外来患者で全体の $50 \%$ では合併症を有する。

表 1 治 験 例 の 構 成

\begin{tabular}{|c|c|c|c|c|}
\hline \multicolumn{2}{|c|}{ 総 数 1,518 例 } & \multicolumn{2}{|c|}{$\begin{array}{lr}\text { 除 外 } & \text { 142例 } \\
\text { 規定数外 } & 42 \text { 例 }\end{array}$} & $\begin{array}{l}(9) \\
(3)\end{array}$ \\
\hline 性 & 男 & 女 & & \\
\hline 1209 & $\begin{array}{l}619 \\
(51)\end{array}$ & $\begin{array}{l}590 \\
(49)\end{array}$ & & \\
\hline 年＼cjkstart齢 & $\sim 39$ & $40 \sim 49$ & $50 \sim 59$ & $60 \sim$ \\
\hline 1044 & $\begin{array}{l}301 \\
(29)\end{array}$ & $\begin{array}{l}196 \\
(19)\end{array}$ & $\begin{array}{l}206 \\
(20)\end{array}$ & $\begin{array}{l}341 \\
(33)\end{array}$ \\
\hline $\begin{array}{c}\text { 期外収縮 } \\
906\end{array}$ & $\begin{array}{c}\text { 上室性 } \\
330 \\
(36)\end{array}$ & $\begin{array}{c}\text { 心室性 } \\
576 \\
(64)\end{array}$ & & \\
\hline $\begin{array}{c}\text { 期外収縮数 } \\
430\end{array}$ & $\begin{array}{c}5 \sim 9 \\
100 \\
(23)\end{array}$ & $\begin{array}{c}10 \sim 19 \\
132 \\
(31)\end{array}$ & $\begin{array}{c}20 \sim 29 \\
163 \\
(38)\end{array}$ & $\begin{array}{c}30 \sim \\
35 \\
(8)\end{array}$ \\
\hline 入 ${ }_{907}^{\text {外 }}$ & $\begin{array}{c}\text { 入 院 } \\
210 \\
(23)\end{array}$ & $\begin{array}{c}\text { 外 来 } \\
697 \\
(77)\end{array}$ & & \\
\hline $\begin{array}{c}\text { 合 併 症 } \\
945\end{array}$ & $\begin{array}{l}\text { 有 } \\
463 \\
(49)\end{array}$ & $\begin{array}{c}\text { 無 } \\
482 \\
(51)\end{array}$ & & \\
\hline
\end{tabular}

不明は除く
表 2 治 験 の 構 成

\begin{tabular}{|c|c|c|c|c|c|}
\hline \multirow[t]{2}{*}{ 全薬剂数 } & 36 & & & & $(1971 \sim 1982)$ \\
\hline & \multicolumn{5}{|c|}{ 群間比較25, 交叉比較11 } \\
\hline \multicolumn{6}{|l|}{ 観察期間 } \\
\hline \multicolumn{2}{|c|}{ なし } & 1 週 & \multicolumn{2}{|c|}{$1 \sim 2$ 週 } & 2 週 \\
\hline & 3 & 25 & \multicolumn{2}{|c|}{4} & 4 \\
\hline \multicolumn{6}{|l|}{ 投与方法 } \\
\hline \multicolumn{2}{|c|}{ 定量 } & \multicolumn{2}{|c|}{ 28, 増量可 } & \multicolumn{2}{|l|}{8} \\
\hline \multicolumn{6}{|l|}{ 投与期間 } \\
\hline \multicolumn{2}{|c|}{1 週 } & 2 週 & 3 週 & \multicolumn{2}{|c|}{6 週 } \\
\hline & 22 & 8 & 4 & \multicolumn{2}{|c|}{2} \\
\hline \multicolumn{6}{|c|}{ 対象基準 } \\
\hline \multicolumn{6}{|c|}{ 不整脈数 } \\
\hline \multicolumn{3}{|c|}{1 分間 5 個 19} & \multicolumn{3}{|c|}{$\left(\begin{array}{l}2 \text { 分間 } 10 \text { 個 } 1 \\
3 \text { 分間 } 15 \text { 個 } 3\end{array}\right.$ を含む) } \\
\hline \multicolumn{3}{|c|}{1 分間10個 } & \multicolumn{3}{|c|}{ （3 分間30個 1 を含む） } \\
\hline \multicolumn{3}{|c|}{ 不 問 } & \multicolumn{3}{|c|}{7} \\
\hline \multicolumn{3}{|c|}{1 分間25個以上 } & \multicolumn{3}{|l|}{2} \\
\hline \multicolumn{6}{|c|}{ 頻＼cjkstart脈 } \\
\hline \multicolumn{3}{|c|}{1 分間 100 以上 } & \multicolumn{3}{|c|}{9 （3 分間300個を含む） } \\
\hline \multicolumn{3}{|c|}{ 不 問 } & \multicolumn{3}{|l|}{1} \\
\hline \multicolumn{3}{|c|}{ 不 明 } & \multicolumn{3}{|l|}{7} \\
\hline
\end{tabular}

II. 成

Placebo を投与された78例の不整脈の実数の変化は 表 3 のごとくで平均では約 $30 \%$ の減少である。

効果判定の基準には統一がない。判定基準を設定し ないもの，4段階判定，5段階判定，アナログスケー ルの使用などが用いられる。 5 段階評価の“有効”以 上をみると $50 \%$ 以上減少を, “著効”には不整脈消失あ るいは $80 \%$ 以上減少を基準としているプロトコールが 多い。

$\beta$ ブロッカーが用いられた症例について, 著効 (卅), 有効 $(+$ ), pp有効 $(+)$, 無効 $(-)$ と主治医が 判定したものの\%は図 1 に示すごとくで著効約 $20 \%$, 有効以上で約 $45 \%$ である。

$\beta$ ブロッカー以外で症例数の比較的多い disopyramide, Ajmaline の成績を, Placeboのそれとくらべて 示したものが表 3 で，著効に相当する75\%以上减少は それぞれ $58 \% ， 41 \% ， 22 \%$ で不整脈別にみると心室性 で特に disopyramideの効果が明瞭である。

安全性についてはかかる短期治験では評価が不可能 といわれるが $\beta$ ブロッカーが投与された 1,017 例をみ ると図 2 のごとく， $\beta$ ブロッカーで報告されている副 作用はほとんど出現している。

以上の成績をみて, 今後不整脈の薬効評価に際し留 意すべき次の点を指摘した。

1）医学上治療を必要とする不整脈数の基準の設定 

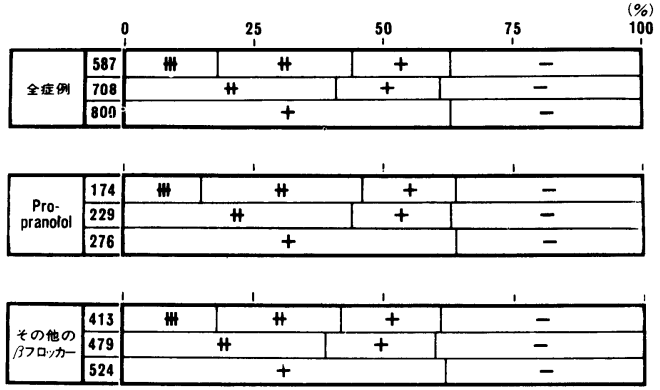

図 $1 \beta$ ブロッカ一の抗不整脈効果（主治 医・全般改善度)

表 3 Placebo

raw dateより

\begin{tabular}{|c|c|c|c|}
\hline & $\begin{array}{l}\mathrm{VPB} \\
\text { 心室性 }\end{array}$ & $\begin{array}{l}\mathrm{APB} \\
\text { 上室性 }\end{array}$ & 全 体 \\
\hline \multirow{2}{*}{1 (27) } & 26.6 & \multirow{2}{*}{ I } & 26.6 \\
\hline & 19.1 & & 19.1 \\
\hline \multirow{2}{*}{2 (12) } & 22.0 & 11.6 & 16.9 \\
\hline & 14.4 & 11.4 & 13.2 \\
\hline \multirow{2}{*}{3 (18) $\begin{array}{l}\text { pre } \\
\text { post }\end{array}$} & 10.3 & 15.2 & 11.9 \\
\hline & 6.2 & 3.7 & 5.3 \\
\hline \multirow{2}{*}{4 (21) $\begin{array}{l}\text { pre } \\
\text { post }\end{array}$} & 17.3 & 16.4 & 17.0 \\
\hline & 15.4 & 13.9 & 14.9 \\
\hline \multirow{2}{*}{$\begin{array}{ll}\text { 全体(78) } & \begin{array}{l}\text { pre } \\
\text { post }\end{array}\end{array}$} & 19.1 & 14.4 & 18.8 \\
\hline & 13.8 & 9.7 & 13.1 \\
\hline
\end{tabular}

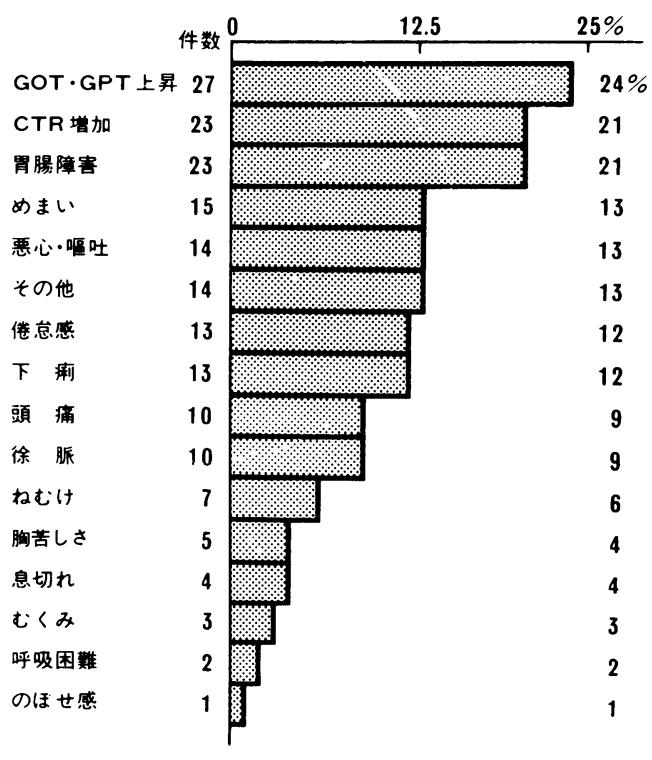

図 $2 \beta$ ブロッカー副作用 $-1,017$ 例の期外 収縮でみられた延べ112件の内訳(\%)
（効果判定の難易で決めるべきではない）。

2）不整脈の種類と重症度の考慮（数の変動だけで よいのか)。

3）効果判定と有用性予測との区別（数が有意に減 少しても臨床的有用性があるとは限らない。症例 数が多ければ少しの減少も有意となる。どれだけ の減少を臨床家は必要と考えるのか)

4）治験症例選択および増量決定に 3 分間 $\mathrm{EKG}$ を 用い，効果判定に DCG を用いることの妥当性

5） $\beta$ ブロッカーを標準薬とする妥当性

6） 3 分間心電図の作為性

2. DCG 期外収縮記録におけ るサイズとパタン

佐久間 昭*

（東京医科歯科大学難治疾患研究所

臨床薬理学部門）

24時間 DCG 記録における期外収縮 VPCの数を経 時データとし，その総数ないし時間あたり平均数をサ イズ, 経過様式をパタンと呼び, この観点からデータ を要約する基本的な考え方を紹介する。

I.スコアー

$\mathrm{n}$ 時点のデータをべクトルとして $\mathbf{y}=\left[\mathrm{y}_{1} \cdots \mathrm{y}_{j} \cdots \mathrm{y}_{n}\right]^{\prime}$ と書く。これに対応させて適当なべクトル $\mathbf{a}=\left[\mathrm{a}_{1} \cdots\right.$ $\left.\mathrm{a}_{j} \cdots \mathrm{a}_{n}\right]^{\prime}$ をつくり, $\mathbf{a}$ と $\mathbf{y}$ の内積 (スカラー積) を

$$
\mathrm{s}=\mathbf{a}^{\prime} \mathbf{y}=\mathbf{y}^{\prime} \mathbf{a}=\sum_{j=1}^{n} \mathrm{a}_{j} \mathrm{y}_{j}=\|\mathbf{a}\| \cdot\|\mathbf{y}\| \cdot \cos \theta
$$

とするが，\|※\|は大ささでたとえば\| $\mathbf{a} \|^{2}=\mathbf{a}^{\prime} \mathbf{a}=\Sigma \mathrm{a}_{j}{ }^{2}$, $\theta$ は $\mathbf{a}$ と $\mathbf{y}$ の狭角である。内積 $\mathrm{s}$ は $\left\{\mathrm{a}_{j}\right\}$ の重及係数を 用いた $\left\{\mathrm{y}_{j}\right\}$ の荷重和であり，多数の $\left\{\mathrm{y}_{j}\right\}$ を 1 個の值 に集約したスコアーにほかならない。

午前, 午後 6 時を境に昼と夜にわけ，それぞれの VPC 数を用いると，もっとも単純なデータ $\mathbf{y}=\left[\mathrm{y}_{1} \mathrm{y}_{2}\right]^{\prime}$ とな る。ある 2 例につき

$$
\mathbf{y}_{\mathrm{D}}=\left[\begin{array}{ll}
6000 & 2000
\end{array}\right]^{\prime}, \mathbf{y}_{\mathrm{N}}=\left[\begin{array}{ll}
1000 & 3000
\end{array}\right]^{\prime}
$$

を得たとする。重み係数を 2 種類考えて

$$
\mathbf{a}_{1}=\left[\begin{array}{ll}
1 & 1
\end{array}\right]^{\prime}, \mathbf{a}_{2}=\left[\begin{array}{ll}
1 & -1
\end{array}\right]^{\prime}
$$

とすれば, D と $\mathrm{N}$ の 2 例については

$$
\mathrm{D}:\left\{\begin{array}{l}
\mathrm{s}_{1}=8000 \\
\mathrm{~s}_{2}=4000
\end{array}, \mathrm{~N}:\left\{\begin{array}{l}
\mathrm{s}_{1}=4000 \\
\mathrm{~s}_{2}=-2000
\end{array}\right.\right.
$$

のスコアーを得る。

この $\mathrm{s}_{1}$ は昼と夜の和, $\mathrm{s}_{2}$ は昼と夜の差であるが, それ 


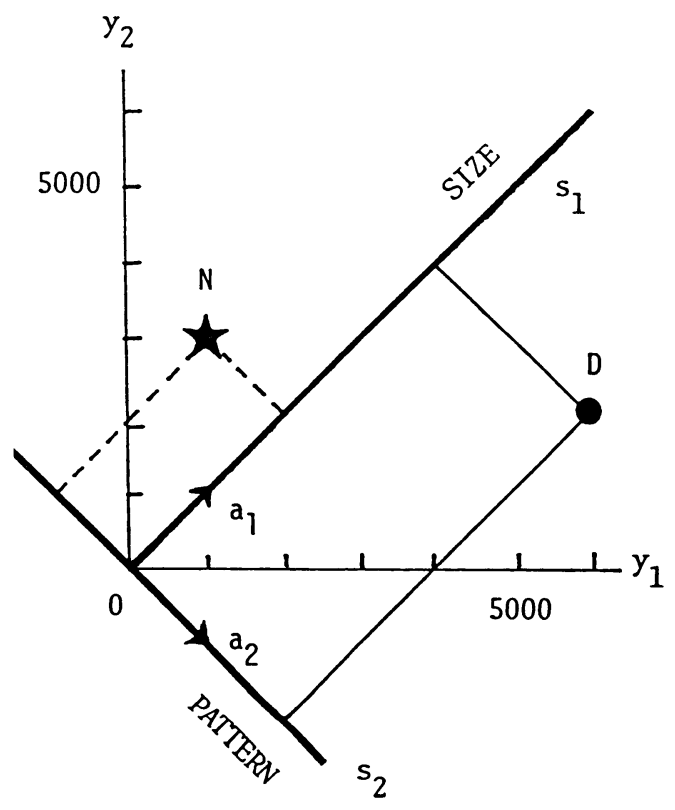

図 1 サイズとパタン（ $a_{1}, a_{2}$ ら1000単位で示す）

ぞれサイズとパタンを示し，Dの方がサイズは大であ り, $\mathrm{S}_{2}$ が正で昼型を意味し，N のサイズは小であるが, $\mathrm{S}_{2}$ が負で夜型を意味する。

図 1 のように $\mathrm{y}_{1}$ に昼, $\mathrm{y}_{2}$ に夜の VPC 数をとり, D と $\mathrm{N}$ のプロットをつくる。ついで原点から $\mathbf{a}_{1}$ の $(1,1)$ の方向と $\mathbf{a}_{2}$ の $(1,-1)$ の方向に直線を引くと, $\mathbf{a}_{1}{ }^{\prime} \mathbf{a}_{2}=$ 0 で $\cos \theta=0$ と直交する新しい軸ができる。この軸か ら D, $\mathrm{N}$ を眺めると， $\mathbf{a}_{1}$ 軸は $\mathrm{s}_{1}, \mathbf{a}_{2}$ 軸は $\mathrm{s}_{2}$ に関係し, それぞれの目盛りは適当に定めるとして， $\mathbf{a}_{1}$ はサイズ 軸， $\mathbf{a}_{2}$ はパタン軸と呼べる。たとえば $\mathbf{a}_{1}{ }^{*}=\mathbf{a}_{1} / \sqrt{2}=$ $\left[\begin{array}{ll}1 / \sqrt{2} & 1 / \sqrt{2}\end{array}\right]^{\prime}$ とすれば $\left\|\mathbf{a}_{1}^{*}\right\|=1$ と規格化されて, 式(1)から $\mathrm{s}_{1}=\|\mathbf{y}\| \cdot \cos \theta$ となり, $\mathrm{D}$ や $\mathrm{N}$ を $\mathbf{a}_{1}$ 上に正 射影，垂直におろす意味がはっきりするであろう。

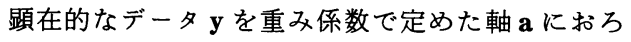

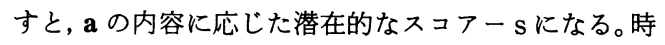
点数を増しても $\mathbf{y}, \mathrm{a}, \mathrm{s}$ の関係は同じであり, $\left\{\mathrm{a}_{j}\right\}$ が ほぼ同程度であればサイズ要素が，また正，負，０と まちまちであればパタン要素が抽出される。 $\{1 \cdots j \cdots$ $n\}$ の時点に $\left\{\mathrm{y}_{j}\right\}$ と $\left\{\mathrm{a}_{j}\right\}$ をプロットしたとき,両者の 経過様式が似ているほど大きな正のスュアーになり, 裏返しで似ていると大きな負のスコアーになり，また 無関係であれば式(1)で $\cos \theta \fallingdotseq 0$ となるから，スコアー はほぼ 0 となる。

\section{II. 主成分分析 PCA}

多数の対象 $\mathbf{y}_{i}=\left[\mathrm{y}_{i 1} \cdots \mathrm{y}_{i j} \cdots \mathrm{y}_{i n}\right]^{\prime}$ をプロットすれば, 昼型, 夜型, 混合型, 総数の大小などによって, バラ
ッキを示すであろら。ある重み係数ないし軸 $\mathbf{a}=\left[\mathrm{a}_{1} \cdots\right.$ $\left.\mathrm{a}_{j} \cdots \mathrm{a}_{n}\right]^{\prime}$ を用いて $\mathrm{s}_{i}=\mathbf{a}^{\prime} \mathbf{y}_{i}$ とスコアーに集約したらえ， $\left\{\mathrm{s}_{i}\right\}$ の分散ないし平方和 $\mathrm{S}_{s}=\Sigma\left(\mathrm{s}_{i}-\overline{\mathrm{s}}\right)^{2}$ が求められる が,この $\mathrm{S}_{s}$ が最大になるように $\mathbf{a}_{1}$ を選ぶことを考える と, この潜在世界での対象間の識別がもっともよいこ とになる。

この $\mathbf{a}_{1}$ と直交した世界で, やはり対象間の識別が最 大となる軸 $\mathbf{a}_{2}, \cdots と$, つぎつぎに軸が定められ，それ ぞれでのスコアーが求められる。各軸の内容をみれば, そこで抽出された潜在的な性質もわかる。これが PCA (principal component analysis) であるが，固有值 問題という，おきまりの手法を用いる。

なおデータ $\mathbf{y}_{i}$ について積和行列 $\mathbf{S}$ といらものが計 算できるが

$$
[\mathbf{S}-\lambda \text { II }] \mathbf{a}=\mathbf{0}
$$

といら式を解くことになる。なおデータについて対象 間のバラッキを求め, $\mathbf{a}_{1}, \mathbf{a}_{2}, \cdots$ のスコアーについての バラッキを求めると，それぞれにどのくらいの分散情 報が移しかえられたかがわかる。

VPC 数のデータでは，サイズ的な $\mathbf{a}_{1} に 50 \%$ 以上が 集約され, パタン的な $\mathbf{a}_{2}$,さらに $\mathbf{a}_{3}$ も加えると全体の 80 90\%が集約されるのが普通であろう。この観点か らみると,たとえば 1 時間ごとの VPC 数を用いた $\mathrm{n}=$ 24 次元のデータの情報のかなりの部分を 3 次元程度 に圧縮できるので, PCA は次元節約の手法といえる。

あらかじめパタンに関心があるなら， $\mathbf{a}_{0}=[1 \cdots 1 \cdots$ 1]を用いて各対象からサイズを除いたらえの制約つ きPCAによって，パタン要素が抽出できる。そのう え, $\mathbf{a}_{1}, \mathbf{a}_{2}$ を経時的にプロットして, その波のうち方を みれば，対象間のバラッキが，どのような波のうち方 について生じているのかが推測できる。

\section{III. 周期回帰分析 PRA}

あらかじめ $\mathbf{a}=\left[\mathrm{a}_{1} \cdots \mathrm{a}_{j} \cdots \mathrm{a}_{n}\right]^{\prime}$ の内容を指定せず，対 象間の識別という規準によって $\mathbf{a}_{1}, \mathbf{a}_{2}, \cdots を$ 求めるの が PCAである。たとえば $\mathrm{n}=24$ 時点について,らねり という観点から, いわば直流のうねりなし $\mathrm{k}=0$, つい で $\mathrm{k}=1,2, \cdots$ 周期のらねりを表現する規則的な重み係 数のセットを用意し,なまデータ $\mathbf{y}=\left[\mathrm{y}_{1} \cdots \mathrm{y}_{24}\right]^{\prime}$ に含ま れているらねり要素を抽出することができるが，これ が PRA (periodic regression analysis) であり, cosinor 法, Fourier（調和）解析と同じ考方方である。

VPC 数のデータの場合, 1 日単位で考えると sine, cosine の関数を利用し, 簡単に $\mathrm{k}=0,1,2, \cdots$ 重み 係数が求められ, 時点を $\mathrm{t}=j-1$ として, $\mathbf{y}=\left[\mathrm{y}_{0} \cdots\right.$ $\left.\mathrm{y}_{23}\right]^{\prime}$ と改めたとき 


$$
\left\{\begin{array}{l}
\mathrm{a}_{t}=\sin \left\{\frac{2 \pi}{n} k t\right\}=\sin \left\{\frac{\pi}{12} k t\right\} \\
\mathrm{b}_{t}=\cos \left\{\frac{2 \pi}{n} b t\right\}=\cos \left\{\frac{\pi}{12} k t\right\}
\end{array}\right.
$$

となる。これらの係数には規則性があるので，実際に は一部分だけ計算すればすむ。 $\mathrm{h}=\mathrm{n} / 2=12$ と打くと， $\sin$ 項は $k=1, \cdots, \mathrm{h}-1, \cos$ 項は $k=0,1, \cdots, \mathrm{h}$ に つき意味をもち，全部で $\mathrm{n}$ 軸が与えられる。これらは 相互に直交し, $\cos$ 項の $k=0$ は $[1 \cdots 1 \cdots 1]^{\prime}$ とサイズ軸 となるが，分散分析的にみれば，修正項 CF にあたる， $\mathrm{n}=24$ のデータは自由度[23]であり, CF 軸を除いた23 の直交軸への分解が PRA であり, 直交分解, Parseval 分解と呼ばれるものの一つの方式になる。

最終的には平均 mesor $\bar{y}$, 振幅 amplitudeA, 位相 acrophase $\phi$ を用いて

$$
\begin{aligned}
\hat{\mathrm{y}}_{t}=\overline{\mathrm{y}} & +\mathrm{A}_{1} \cos \left\{\frac{2 \pi}{n} 1 \mathrm{t}-\phi_{1}\right\} \\
& +\mathrm{A}_{2} \cos \left\{\frac{2 \pi}{n} 2 \mathrm{t}-\phi_{2}\right\}+\cdots
\end{aligned}
$$

の形式でデータが表現される。 $\bar{y}, A_{1}, \phi_{1}, A_{2}, \phi_{2}$ な どの少数のパラメターに要約して, 対象相互の比較が できることも少なくない。

\section{〔文献〕}

1）佐久間昭：薬効評価 II, 東大出版会（1981）

\section{3. 視察的概括評価の構造}

\section{（*東京医科歯科大学難治疾患研究所 \\ 臨床薬理学部門)}

心室性期外収縮 (VPC) の発現には日内変動が存在 する。1981年に実施された $\beta$ 遮断剂のVPCに対する 二重盲検比較試験において, $24 \mathrm{hr}-\mathrm{DCG}$ 記録をもと に, VPCの日内変動パタンを加味した, 概括改善度の 判定が行われた。この際のデータにつき，その判定構 造と, 同時に記録された 3 分間 ECG との関係を検討 した。

記録の完全な70例を対象として，図 1 に示すような 1 日を $4 \mathrm{hr}$ ごとの 6 時点にまとめた VPC 数の経時 プロット図を用いて 5 名の循環器専門医がそれぞれ独 立に 3 十から 2 -までの 6 段階に, 視察的に概括評価 を行った。

図 1 に 1 日総 VPC 数として $32 \%$ 前後の減少率を示
した 3 例を示す。ある評価者は $\mathrm{A}, \mathrm{B}, \mathrm{C}$ にそれぞれ0， $2+, 2+$, といら判定を下した。A，Bの判定のちが いは, A では約 $5,000 \rightarrow 3,600, \mathrm{~B}$ では約 $15,000 \rightarrow$ 12,000という初期值のちがいにより, 同じ減少率でも 初期値の高いもの活どよく改善されたといら価值判断 が入ったものと思われる。この考えにたてば, C は少な

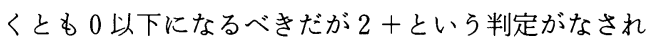
ているのは, Cではパタンの変化が大きいことが関係 しているものと思われる。

すなわち, 一日総 VPCの変化分, 初期值, パタンの 変化の 3 つの要素が判定に関与しているらしい。第 3 の要素である観察期から治療期への VPCのパタンの 変化を計量化するため, 各 6 時点にまとめた VPC 数 の差分データを用い，サイズを除く制約をつけた主成 分分析 (PCA) を適用した。

PCAによりえられた 5 つの主成分の重み係数から 求めた各患者のもつパタンの動きとしてのスコアを, 一日総数の変化(差ないし比), 初期值と共に説明変数 とし, 判定を目的変数として, 重回㷌分析 (MRA)を 行い,この 3 つの要素の判定に対する関与を検討した。 結果は図 2 に示すように, 差を考えても, 比を考えて 当総 VPC 数の変化といらサイズの関与が $50 \%$ 程度で あり，初期值とパタン要素の関与は小さかった。

偏回帰係数の内容からみると, 差の場合と比の場合 では初期値の影響は逆方向であり, 差の場合, 同じ 2,000 の減少でも $10,000 \rightarrow 8,000$ の例と $4,000 \rightarrow 2,000$ の 例では, 初期値の大きな前者ではやや辛く, 初期値の 小さな後者ではやや甘く判定される傾向がみられた。 これに対して比の場合同じ $1 / 2$ の減少でも $10,000 \rightarrow$ 5,000 の例に対して $4,000 \rightarrow 2,000$ の例ではやや辛い判 定となり，初期值が小さいときには，自然変動を加味 したらえ, ほぼ０にならなければ改善とはしないとい ら価値判断がなされていることがうかがわれた。

評価者 5 名の判定が完全に一致した例は約 $25 \%$ と少 ない。そこで判定の不一致の理由を探索する目的で, 判定のずれの小さな対象と大きな対象の 2 群に分割し たらえ，あらためて MRAを行った。図 3 に示すよう に, 判定のずれの小さな群では説明変数としては総 VPC 数の変化が重要であり関与率は約 $65 \%$ となる。判 定のずれの大きな群ではサイズ要素に加え, 初期値, パタン要素も大きく関与し，さらに評価者によって関 与率の大きさやパタン要素の内容について差が認めら れ， 2 群に関しての判定構造は明らかに異なるものと 考えられた。初期値の小さなもの, パタン変化の大き いものでは評価者の解釈が異なり, 判定に不一致を生 じやすいことが判明した。

今回のデータでは DCG 記録の前後に 3 分間 ECG の記録がとられている。VPC 数の改善度といら観点か ら観察期から治療期にかけての VPC 数の差や比につ 

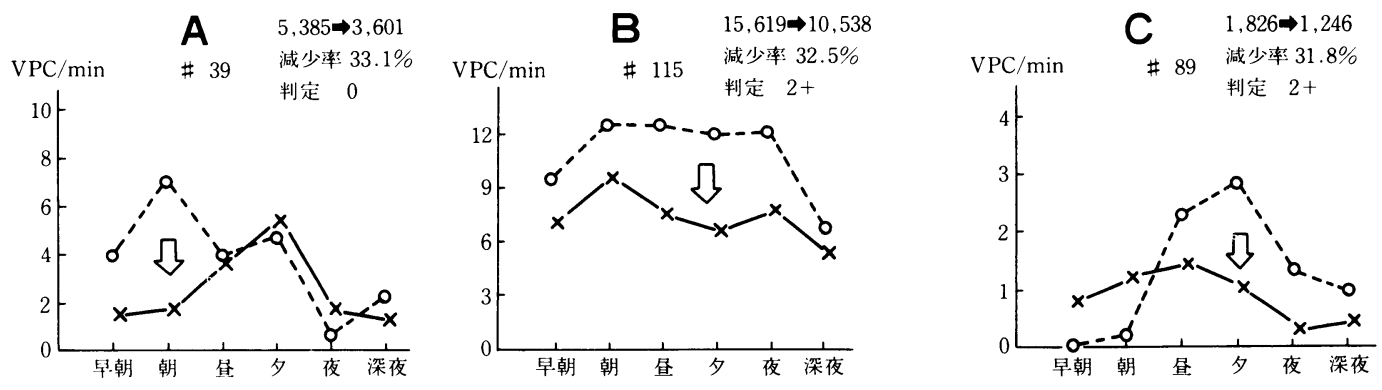

図 1 一日総 VPC 数として，ほぼ同じ減少率を示したにもかかわらず判定が異なった 3 例

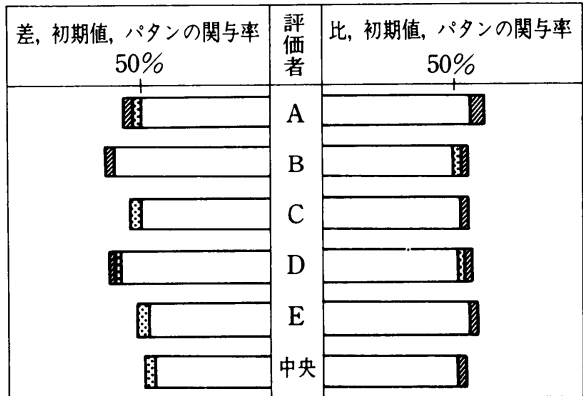

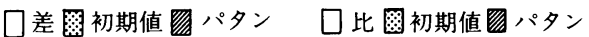

図 2 判定に拈ける差ないし比, 初期値, 八 タンの関与率
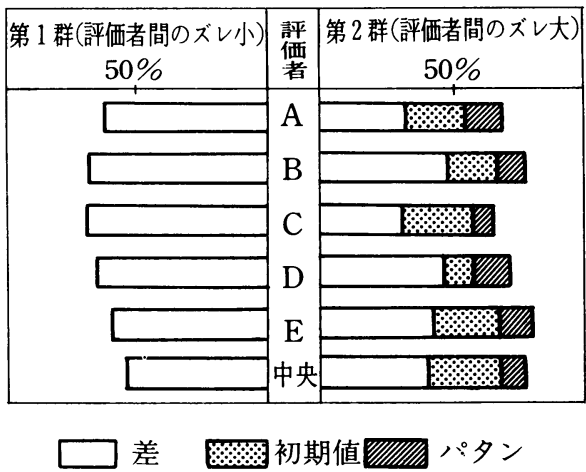

図 3 評価者間のズレ大小の 2 群における 差, 初期值, パタンの関与率

いて対比させると，24 hr-DCG 記録と 3 分間 ECG 記 録との間の Spearmanの順位相関係数は0.6 0.7程 度になり（図 4 ），3 分間 ECG 記録での改善率がやや 高いが，ECG 記録の時刻が関係しているらしい。

DCG を ECG の反復とみれば，個体内情報は格段に 増加するが，個体間情報の増加は例数の増加によって のみ可能となる。VPC 改善度の主たる内容はサイズ要

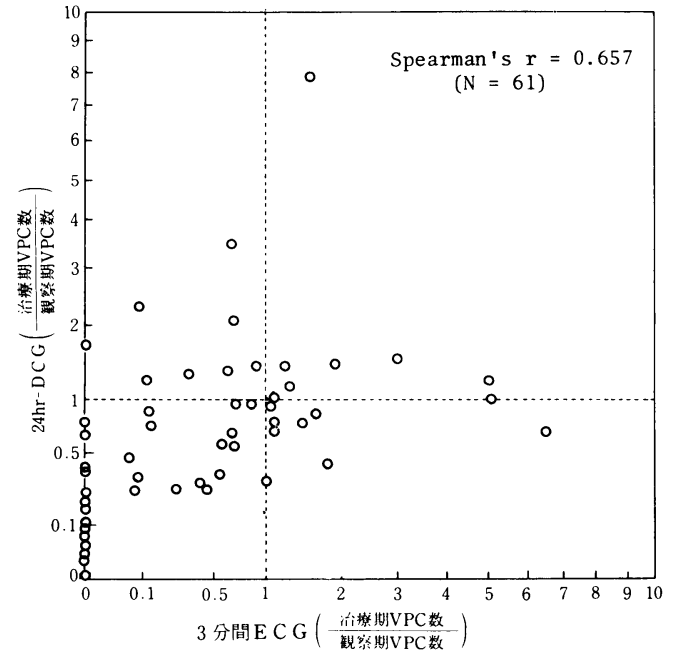

图43 分間 $\mathrm{ECG}$ と $24 \mathrm{hr}-\mathrm{DCG}$ による VPC 比 (治療期/観察期)

素であることが示されたが, DCG, ECG 記録の間にサ イズ要素に関してある程度の正相関が認められるた め, ECG 記録も，集団的なアプローチをとる無作為化 比較試験では薬剤間の差を各薬剂群内での個体間情報 に対比させて薬効評価を行うのであるから，なお意味 をもつと考兄られる。

個体的な薬効評価のみならず，集団的な薬効評価に 打いても，24 hr-DCG 記録を利用するにあたっては, サイズのみならず，パタンの要素も考慮しなければ, 記録に要する患者, 医師の負担も併せ考えるとき, DCG 記録の本来の特長は半減することになろう。

\section{〔文献〕}

1）宮下英夫ほか：Metroptolol の心室性期外収縮に 対する治療効果, Progress in Medicine 投稿中

2）津谷喜一郎：心室性期外収縮改善度評価における サイズとパタンの意味, 臨床薬理, $13 ： 595,1982$ 


\section{4. 有意性検定の注意点}

橘 敏明*

（*愛知県心身障害者コロニー発達障害研究所）

米国の心理学者を対象とした調査によると, 研究者 はポジティブな結果の追試で，有意な差を得ることに 過大の期待をもっているという（Tversky \& Kahneman, 1972)。たとえば，標本数20である実験を行い， その結果, $Z=2.23, \mathrm{p}=0.02$ (両側検定) というデータ

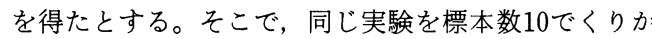
えした場合に，再び有意な差を得る確率（片側検定， $\alpha=0.05$ がいくらになるかを問うたところ，その回答

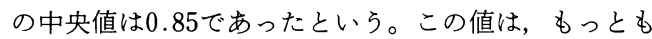
妥当と考兄られる值, 0.47 とは大きく異なっている。 統計的パワーとは，母集団間に何らかの差がある場合 に，統計検定でその差を有意な差として検出する確率 をいらが，先の調査は，パワーについての理解に欠け ている研究者が多いといらことを示している。

パワーは母集団間の平均の差, 分散, 有意水準, 標 本数と関係しており,とりあつかいがめんどらである。 そこで，母集団の平均の差と分散を effect size といら

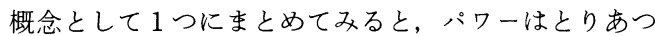
かいやすくなる。この概念は

effect size $=$ 母集団間の平均の差/母集団の分散 であらわされるが，2つの母集団の分布が重なり合わ ない面積の\%を示す指標でもあらわされる。

表 1 は，2つの母集団のちがいを effect size として とらえ，有意な差を得る確率が，標本数とどのような 関係にあるかを示したものである。たとえば，2つの 母集団間の差が effect size $=0.5$ (これは 2 つの集団 の重なり合わない部分が33\%にあたる）の場合は，各 群の標本数を 8 とすると, $\mathrm{t}$ 検定を用いると, 有意な差 として検出する確率は 0.15 となり，標本数を 50 とする と，その確率は 0.70 となる。標本数が大きいと，パワ 一が大きくなる。そして，標本数をさらに大きくする と，ほとんど確実に有意な差を得ることになる。

有意性検定でもっともよく用いられる検定論理は， 母集団間の差がゼロかゼ口以外かといらことである。 この場合，わずかでも母集団間に差があれば，標本数 をふやすことで有意な差として検出できることにな る。

現実には, 実験群とその対照群で, たとえば $\mathrm{p}<0.01$ で有意な差があると，その差を意味のある差として議 論する場合が多い。しかしこれは母集団間に何らかの 差（それが大きな差とはかぎらない）があるらしいと いうことを示しているにすぎない。有意な差があると
表 1 パワー, effect size，標本数の関俰

\begin{tabular}{ccccc}
\hline \hline & \multicolumn{2}{c}{ Effect Size } & \\
\cline { 3 - 4 } 標本数 & $\begin{array}{c}0.2 \\
(15 \%)\end{array}$ & $\begin{array}{c}0.5 \\
(33 \%)\end{array}$ & $\begin{array}{c}0.8 \\
(47 \%)\end{array}$ \\
$\mathrm{n}$ & 8 & 0.07 & 0.15 & 0.31 \\
$\alpha=0.05$ & 50 & 0.17 & 0.70 & 0.98 \\
& 20 & 0.09 & 0.33 & 0.69 \\
& 100 & 0.29 & 0.94 & $*$ \\
& 200 & 0.51 & $*$ & $*$ \\
& 1000 & 0.99 & $*$ & $*$ \\
\hline
\end{tabular}

(two-tailed)

(* greater than 0.995 )

表 $2100 \pm 10$ と108土10の差にみられる 標本数 $(\mathrm{n})$ と $\mathrm{p}$ 值の関係

\begin{tabular}{rll}
\hline \hline $\mathrm{n}=8$ & $\mathrm{t}=1.50$ & $\mathrm{p}=0.153$ \\
$\mathrm{n}=20$ & $\mathrm{t}=2.47$ & $\mathrm{p}=0.017$ \\
$\mathrm{n}=50$ & $\mathrm{t}=3.96$ & $\mathrm{p}=0.0003$ \\
$\mathrm{n}=100$ & $\mathrm{t}=5.63$ & $\mathrm{p}=0.000007$ \\
$\mathrm{n}=200$ & $\mathrm{t}=8.00$ & $\mathrm{p}=0.0000001$ \\
\hline & & (two-tailed)
\end{tabular}

いらことは，その差が意味のあるほど大きな差である ということを保証しているわけではない。標本数さえ ふやせば，どんな小さな母集団間の差でも，有意な差 として検出できるからである。

表 2 は, パワーと標本数の関係を別の見方で示した ものである。標本で得られた群の平均の差と標準偏差

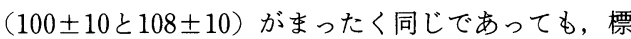
本数が異なれば，その $\mathrm{P}$ 值は異なってくる。

このように，有意差の有無が母集団のちがいの大き さとは別に, 標本数にも依存しているということは, 薬効の評価に，有意性検定のみを用いることは危険で あることを示している。そこで，標本数の影響をうけ ず，しかも薬効の度合いを敏感に示す指標として，関 連度 (strength of association) といら統計量を用い ることがす寸められる。この指標は, 独立変数と従属 変数の関連の強さを示すものである。すなわち, 従属 変数の分散のうち，独立変数によって説明できる割合 を示している。

たとえば $\mathrm{t}$ 検定では，その値は 関連度 $=\mathrm{t}^{2} / \mathrm{t}^{2}+$ 自由度

で示される。

試験薬が基準薬と効果が同じであるといらことを主 張したり，あるいは有害作用の発生が試験薬とプラセ ボで差がないということを主張したりする場合に，単 に両群に統計的に有意差がないといらことを示すこと 
ですませている場合が多い。しかしこれは誤った論理 である。たとえ検定で有意な差がなかったとしても， タイプIIのエラー（群間の差をみのがしている確率） が大きければ，そのような主張はできない。有意な差 がないといらことは，タイプIIのェラーが十分に小さ いといら保証を与えているわけではない。

両群の母集団間に差がないといらことを積極的に主 張するには，有意差がないといらことを示すだけでな く，そのように判断を下したさいにおかしらるタイプ II のエラーが十分に小さいといらことを示さなければ ならない。

具体的には次のような論理の手続きをふむことにな る。まず，どの程度の群間の差ならみのがしてもよい といら值を決める。これは effect size を決めることで 決まる。ついで, 標本数, 有意水準をどこにおくかを 決める。これらが決まれば，母集団間の差を有意な差
として見い出す確率，すなわちパワーを決めることが できる。この計算には Cohen (1977) の表が便利であ る。そして1からこのパワーを引いた值がタイプIIの エラーとなる。この值が十分に小さいと,たとえば $\mathrm{p}<$ 0.01 であるとき, 両群に差がないという主張のための 根拠ができる。ただしこの值は固定的なものではなく， みのがしを許容する effect size の値を別の值に設定 すれば，タイプIIのエラーは別の確率となる。

\section{〔文献}

1) Cohen $J$ : Statistical power analysis for the behavioral sciences. New York, Academic Press, 1977

2) Tversky A \& Kahneman D : Psychologicall Bulletin $76: 105,1972$ 